\title{
Natura 2000: The European Way Towards Sustainability
}

\author{
Jesús María Garayo Urruela \\ Faculty of Political Sciences and Sociology, University of Deusto (Bilbao), Basque Country, Spain
}

\section{Email address:}

jmgaraio@euskalnet.net

\section{To cite this article:}

Jesús María Garayo Urruela. Natura 2000: The European Way Towards Sustainability. Earth Sciences. Vol. 10, No. 5, 2021 , pp. $225-233$. doi: $10.11648 /$ j.earth.20211005.14

Received: August 28, 2021; Accepted: October 14, 2021; Published: October 29, 2021

\begin{abstract}
Since the entry into force of the Habitats Directive (92/43/EEC) on 9 June 1994, the Natura 2000 Network has become the tool conceived by the Community authorities to lead the implementation of the environmental commitments on European territory, to which they were bound in application of their accession to international conventions. Natura 2000 pursues the conservation of biodiversity in Europe by harmonizing the conservation of natural heritage with the support and promotion of traditional human activities. The Habitats Directive formulated the principles, objectives, management measures and procedures to preserve, maintain or, where appropriate, restore biological diversity, which each State was subsequently responsible for transferring to the jurisdiction. The standard does not impose any specific method to be used in the designation of the sites, the type of management to be developed or the measures to be implemented, but it does establish control mechanisms over their application. The designation of a Natura 2000 site provides an invaluable opportunity to stimulate the sustainable rural development of the area and to promote plans and activities compatible with the conservation of habitats and protected species. Dialogue and concertation are the mechanisms to be put into practice when it comes to resolving conflicts arising from the design of management models that articulate the recovery of the environmental heritage. The model by which the Natura 2000 Network has been implemented so far in Spain, and specifically in the Autonomous Community of the Basque Country, has been based on technocratic-formal processes. The inclusion of the area in the Natura 2000 network tends to be perceived by the inhabitants of the rural world as a bureaucratized process, disconnected from local plans and collective projects. The considerable delay in the designation of areas protected by the Natura 2000 network has contributed to the delay in adopting appropriate measures to promote biodiversity and achieve the objective of halting biodiversity loss in Europe in the short term. Despite having redoubled efforts in favor of conservation, the processes of environmental degradation have been increasing.
\end{abstract}

Keywords: Sustainable Development, Nature Conservation, Protected Sites, Basque Country, Spain, EEC

\section{Introduction}

Studies promoted during the eighties of the 20th century by the European Commission confirmed the homogenization and loss experienced in the European territorial scope from the point of view of diversity: more than $33 \%$ of the 900 species of invertebrates and more than $22 \%$ of the 11.000 plant species were at that time in a threatened situation [1]. The Commission itself recognized that two-thirds of the wetlands and almost three-quarters of the dunes and heaths had been lost on European territory between 1900 and the mid-1980s [2]. Environmental erosion was caused, in some cases, by the regression and fragmentation of natural environments derived from urban expansion, the development of infrastructures and the intensification of industrial and agrarian production or, in others, it came from the degradation of semi-natural habitats as a consequence of the decline in extensive agricultural and livestock practices as a result of the rural exodus and the agrarian crisis.

The holding of the First Earth Summit in Rio de Janeiro (1992) increased concern for the environment and sensitivity for sustainable development. In this social context, the European Commission agreed in 1992, on the one hand, to deepen the reform of the Common Agricultural Policy (CAP), in force since 1962, and on the other, to launch the Natura 2000 Network.

The environmental problems of the European territory were attributed in part to the CAP, on the understanding that the subsidies and public aid established in the field of market 
protection, had resulted in a stimulus to the intensification of production and, therefore, in a greater use of machinery, fertilizers, biocides, etc. [3], with consequent problems in the environmental fields (soils, water, biodiversity,...) and landscape (deterioration due to the cessation of agricultural and livestock uses on marginal lands).

The European Commission, which in the course of the eighties, adopted various measures to tackle an increasingly unsustainable CAP from budgetary and market discipline, agreed to deepen the review of the agricultural model with a view to promoting respectful rural development and balanced with environmental requirements. In this sense, the Presidency of the Council of Ministers of Agriculture consensually accepted the idea that to conserve the vegetation cover and nature as a whole, the presence of a sufficient population in rural areas was necessary, with an adequate level of services, and income and demanded to this end, among other measures, the promotion of extensive cattle ranching [4]. The MacSharry reform also came to recognize that the maintenance of healthy agrarian structures was a necessary condition to guarantee the preservation of the landscape and the conservation of the natural environment [5]. For this reason, measures aimed at promoting agricultural production methods compatible with the requirements of environmental protection and conservation of the natural environment were approved in June 1992, and aid was established for the afforestation of agricultural lands and early retirement ${ }^{1}$. The reform paved the way for subsequent revisions of the CAP, in which aid aimed at agricultural production progressively ceased to be a priority and, instead, rural development policies integrated with environmental conservation gained more and more force.

In parallel, the European Commission launched Natura 2000, a program called to promote harmonized policies in order to protect biodiversity (habitats and species) and stop the degradation of the European environmental heritage. The inspiring technical and legal bases of Natura 2000 can be found in the Bonn (06/23/1979) and Bern (09/19/1979) Conventions and in the Rio de Janeiro Conference (June 314, 1992). The Bonn Convention, an intergovernmental treaty promoted by the UN, deals with the conservation of wildlife and habitats on a global scale, paying special attention to the conservation of migratory bird species. The aim pursued by the Berne Convention is to promote cooperation between European countries in order to promote and guarantee the conservation of wild flora and fauna. The first Earth Summit contributed to transfer to the public agendas the interest in biodiversity and an innovative approach to its conservation, with a particular recommendation to promote traditional agricultural practices

1 Council Regulation (EEC) No. 2078/92 of June 30, 1992, on agricultural production methods compatible with the requirements of environmental protection and conservation of the natural environment; Council Regulation (EEC) No. 2079/92 of June 20, 1992, which established a Community scheme of aid for early retirement in agriculture; Council Regulation (EEC) No. 2080/92 of June 20, 1992, which regulated a Community aid scheme for forestry measures in agriculture. and, specifically, extensive livestock farming ${ }^{2}$. With the Declaration on Environment and Development and the Convention on Biological Diversity, approved within or around the Rio Conference, the association of biodiversity and sustainable development was enshrined and since then, they began to be common in the government programs on the environment ideas such as the integration of the environmental dimension with economic and social aspects, the management of vast territories in order to halt the accelerated loss of biodiversity, the direct intervention in protectionist programs by economic and social agents involved, etc.

The constitution of an ecological network, mentioned in the Birds Directive (79/49/EEC), was endorsed as a result of the debates that arose around the Bonn Convention. The idea, taken up and completed thirteen years later, became the axis around which the text of the Habitats Directive (92/43/EEC). The Council of Europe approved this directive on May 22, 1992 and it entered into force on June 9, 1994³. Natura 2000 was the tool conceived by the community authorities to lead the implementation of the commitments on European territory, to which they were bound in application of the Berne Convention and by its adherence to international conventions on environmental issues.

\section{Integration of Conservation with Development}

The Habitats Directive urges Member States to establish the necessary measures to preserve, maintain or, where appropriate, restore biological diversity. By article 6, the Directive urges them to establish conservation measures and to adopt proposals to avoid environmental deterioration and alteration ${ }^{4}$. The management measures include the regulatory (declaration of the protected natural area), administrative (management plans, evaluation of plans and projects, financing funds, compensation systems) and contractual (agreements with owners). The network was conceived as an instrument that pursued the conservation of biodiversity as a

\footnotetext{
2 The Declaration of the Earth Summit, a document approved at the United Nations Conference on Environment and Development, held in 1992 in Rio de Janeiro, contains an express mention of the role played by extensive livestock in aspects such as the conservation of diversity. of the heritage of rustic animal breeds (Principle 14.65) and the management of the natural environment through the traditional knowledge and practices of peasants and indigenous people (Principle 22).

3 The Habitats Directive was subsequently modified and updated by Council Directive 97/62/EC of October 27, 1997, in order to update certain types of natural habitats and certain species of Annexes I and II of Directive 92/43/ECC according to scientific and technical progress [6].

4 Beyond the conciseness of the legal text, the Commission has published several technical guidance documents in order to ensure a consistent application of Article 6 in the Member States: a) a manual for the interpretation of Article 6 of the Habitats Directive [7], updated by a recent version published in January [8] and b) methodological guidelines on paragraphs 3 and 4 of article 6 in relation to the evaluation of plans and projects [9]. Both documents, in any case, are not binding, since, ultimately, it is up to the European Court of Justice to interpret the contents of the Commission's Directives.
} 
direct objective, with progressive progress towards more sustainable economic development as a more general goal in the medium and long term.

Natura 2000 sets itself as aspiration the identification, selection, mapping and protection of the most outstanding natural resources in European territory due to their quality, rarity or vulnerability. In order to safeguard the diversity and surface area of habitats, necessary for the survival of protected fauna and flora (arts. 3 to 11), the Directive included 231 types of habitats, in addition to 300 animal species and almost 600 plant elements of "Community interest" (Annexes I and II), of which some 70, 50 and 200, respectively, were considered "priority". Habitats and species are organized and framed in biogeographic regions, which after expansion to the eastern countries, consist of Alpine, Atlantic, Boreal, Continental, Stepic, Macaronesian, Black Sea, Mediterranean and Pannonian. The selection of habitats is governed by the criteria of exceptionality, representativeness of the distinctive characteristics of each biogeographic region and degree of support of biodiversity, while in species, the accent was placed on vulnerability (endemisms, rarity,..), population dynamics and conservation status of their respective habitats. Depending on the advancement of scientific knowledge, the subsequent incorporation of species or habitats not included in the annexes remains open, if their characteristics respond to the spirit and objectives of the Directive.

The definition of the habitats and species to be protected, the selection and demarcation of designated areas, the proposal of management measures or the evaluation of results in the application of the latter are tasks entrusted by the Habitats Directive to scientists and naturalists. The experts perform a crucial and determining task within the network of processes configured in Natura 2000 [10, 11]. The directive, in this case, reflects something specific to modern society, in which human interactions with nature are organized in accordance with prescriptions supported by the knowledge available in the field of natural sciences [12]. The resource and support in science, sought, on the other hand, to favor the political and social legitimation of the conservation program.

Natura 2000 represents above all a qualitative leap in the strategy of conservation of the natural environment, by proposing the creation of a coherent and large-scale ecological network within the European space [1, 13]. Underlying the network management approach is the currently widely shared idea of an integrated management of protected areas to replace a structured conservation strategy in islands of biodiversity surrounded by an environment deeply altered by intensive human activities [14-16]. Natura 2000 , therefore, does not propose to establish sanctuaries for wildlife, but rather recognizes that the human being is another part of nature.

The Directive designs a proposal for the convergent conservation of nature, in which protected areas are managed so that they are all linked by means of connections and corridors. The combination of concepts such as network and habitats allows us to overcome the classic model, based on lists of emblematic species and especially outstanding areas; The directive does not place the accent on conserving spaces or species but on protecting the diversity of living beings that inhabit European territory [17]. The adoption of the concept of network also represents a step in the direction of combining in vast areas of the European territory the protection of "outstanding" nature with others, not so prominent, although important, which are included among those classified as "common" nature". The text, in any case, is not alien to the principle of hierarchy of spaces; the idea of zoning subsists in some way and with it, the safeguarding of territorial fragments with more or less high ecological value continues to face intensive productive uses by man in the rest of the territory [18]. The setting of burdens and limitations on production (arts. 12 to 16) also shows the persistence of measures consistent with classical and rigid approaches to understanding protectionist policies. However, Natura 2000 embodies a daring invitation to reconcile man and nature through sustainable or eco-conditioned development: within the areas delimited according to scientific criteria, it is not promoted to exclude man but to manage and regulate his action on the nature in order that both parties benefit.

European environmental regulations seek to adapt and combine biodiversity with economic, social and cultural requirements and different regional and local realities. Specifically, the second article sets the objective of guaranteeing biodiversity, maintaining natural habitats and wild fauna and flora of community interest in a favorable state of conservation and adopting measures in accordance with the economic, social and cultural requirements and the regional and local particularities. The conservation of habitats and species is conceived as an integral management of the territory, which encompasses human beings and their activities as one more factor that affects the natural environment and without affecting, therefore, always negatively on its maintenance and conservation ${ }^{5}$. The Natura 2000 Network aims, from this perspective, to harmonize the conservation of the local natural heritage with the support and promotion of traditional human activities that, in short, have contributed to its preservation and to the conservation in good condition of the habitats and species cataloged of community interest by the European institutions ${ }^{6}$. The

5 Council Directive 92/43/EEC of 21 May 1992 on the conservation of natural habitats and wild fauna and flora, OJ L 206, 22.7.1992, 6. In this sense, the preamble of the Directive, in the third recital, integrates biological conservation with the economic, social and cultural reality of the environment, stating that "since its main objective is to promote the maintenance of biological diversity, while taking into account economic, social, cultural and regional rights, this Directive will contribute to the general objective of sustainable development" and "that the maintenance of this biodiversity may in certain cases require maintenance or even encouragement, human activities", according to page 2 of reference 23 .

6 The protection regime of the places designated as Natura 2000 is homologated in the classification system elaborated by the UICN (1994) to category V called "Protected terrestrial and marine landscape", that is, with protected areas destined to simultaneously conservation and development under the strategy of transferring conservation interventions to an "ordinary" and "common" nature $[24,25]$. 
management of the Natura 2000 Network is therefore not understood without the cooperation and direct participation of those local agents that historically managed the natural environment and protected landscapes.

The practical translation of the Directive is complex and even problematic, since the origin of each intervention lies in a scientific expertise that, on the other hand, has to converge with the requirements presented by the economic and social context of each protected place. The management runs through a diagnosis to be carried out in each designated space, which starts from cultural visions and confronted socio-economic projects, although legitimate. With Natura 2000, political representatives and local inhabitants discover ecology and come into contact with biologists and experts in nature conservation [19]. For scientists and naturalist managers, safeguarding biodiversity requires regulating it through the application of management guidelines aimed at preventing it from being threatened by human action.

Farmers and ranchers, for their part, are confused and do not quite understand that if a space has been chosen for its biological richness, the result in large part of the management deployed by the predecessors and themselves, it is now intended that they must be in the right position. successive subject to an external auditor, who also imposes limitations on the uses of the space [20]. The clash of these two opposing representations of the socio-ecological intervention give rise to tensions and conflicts. The resolution by rapprochement, dialogue and negotiation will contribute to the articulation of the appropriate context to successfully solve the challenge represented by Nature 2000: confrontation of knowledge and practices, meeting of common visions, fixing of concerted commitment and promotion of mixed management models that integrate what has been validated by the practice of both approaches on the path of associating human activities compatible with the preservation of more or less outstanding agroecosystems [17, 20-22]. Natura 2000, for all this, is articulated in a laboratory of experiences under the common objective of deploying an ecological management that enables the recovery of European environmental heritage.

Natura 2000 starts from the fact that the biological richness of a place depends on the complexity of the ecosystems that compose it. The commitment to maintain the representation of each type of habitat of community interest throughout its occupied area may entail in some cases the execution of selective logging, while in others, it results in avoiding natural afforestation through clearing, the use of fire. or the introduction of rustic breeds. Ultimately, the challenge lies in conserving landscapes and the diversity of habitats in structural, landscape and biological diversity terms, even proceeding, if necessary, to slow down changes in ecological dynamics. The network is conceived as an instrument aimed at conserving and maintaining Europe's biodiversity based on sustainable development models. Anyway, the management and conservation of natural habitats and species of community interest mostly involve maintenance and restoration. of those human activities, which have managed to preserve up to the present the biological heritage of montane spaces in the form of a mosaic.

\section{Management, a Responsibility of Each Member State}

The environment is a competence assumed by the EU as a result of the Single Act (1986) and the Mastrich Treaty (1992), but shared with the Member States in application of the principle of subsidiarity. European environmental regulations, therefore, formulate principles, objectives, and content that each State is responsible for transferring to its area of jurisdiction. The Directive, in this sense, does not impose any specific method to be used in the designation of the sites, the type of management to be developed or the measures to be implemented. Article 10 of the Directive introduces the concept of corridors and biological continuums, but leaves the freedom to choose their size and location to the States. In the application of the Directive, there is room for regulatory policies imposed unilaterally by the public powers as well as more conciliatory policies, based on sustainable development articulated in dialogue and negotiation; The contractual methodology applied in the United Kingdom or France constitutes an interesting and remarkable example of the latter [11, 16, 26-28]. Management varies from one country to another: centralized in some northern European countries or decentralized in Germany, Belgium, Spain or Sweden, a country in which the management of the program can even be entrusted to the municipalities. In Greece, mixed management formulas have been implemented, in which private management and public control are associated. The application of agro-environmental measures is widespread in most countries.

The Directive, in any case, provides control mechanisms in its application by the member states, which, under sanction, require the obligation to monitor the state and trends of conservation of the habitats and species included in the Annexes. II, IV and V (art.11) and based on it, it entrusts them with the drafting of a six-year evaluation report for subsequent referral to the corresponding community bodies (art.17). The first reports (1994-2000) logically focused on the transposition of the Directive into state legislation [29], while those corresponding to the six-year terms 2001-2006 and 2007-2013 already addressed the checking of the conservation status of habitats and species [30, 31]. The mandatory report, planned to be carried out every three years on the application of the same by article 12 of the Birds Directive has been modified by the Commission in order to unify the information and temporal scope of issuance with the demands required by article 17 of the Habitat Directive. The report became six-year and thus the evaluation operations provided for in the European Directives on Nature coincided in time [31].

The areas protected by the Natura 2000 Network can be of two types: Special Area of Protection (SAP) and Special Area 
of Conservation (SAC). The SPAs derive directly from the old Areas of Conservation of Wild Birds (ACWB) and comprise the most suitable territories in number and in area to ensure the good state of conservation of threatened, vulnerable or rare bird species. The declaration of SAPs is made at the national level without the need for negotiation with the European Commission. In the designation of the SACs, however, each State begins the process with the identification of possible sites in its territory, likely to be included as such, and sends a state list in the form of a proposal. The European Commission, once the documentation has been approved and completed, proceeds to register the places as SCIs. The designation of a space as SAC formally triggers the application of positive management measures (Article 6.1). Similarly, the qualification as sites of Comunity Importance (SCI) implies the application of preventive safeguard measures in order to prevent their deterioration (Article 6.2), as well as the obligation of the authorization procedure of new plans or projects that may have an appreciable effect on the place (Articles 6.3 and 6.4). The same place can simultaneously have the classification as ACWB and SCI/SAC.

The European network of protected areas was expected to be created all at once and within a maximum period of twelve years, that is, by June 2004. In articles 4 and 5 of the Habitats Directive, three successive phases were established as regards the SACs configuration process: after the state proposals for the list of spaces to be included in the Natura 2000 Network (June 1995), the European Commission would proceed to approve the definitive lists of SCIs for each biogeographic region (June 1998) and, from that moment and within a period of six years ${ }^{7}$, the public institutions, competent in each case, would provide the corresponding management regimes to each of the SCIs as a condition for their designation as SAC.

The management of the places designated in the Natura 2000 Network requires actions in fields such as studies, activities, conservation measures, infrastructures, etc., impossible to carry out without the corresponding funding. The Habitats Directive, by article 8 , establishes community co-financing, in view of the fact that the objectives pursued, the promotion of the conservation of habitats and species of community interest, are the common responsibility of all member states, while distribution territorial of the same is uneven by the European space. In order to avoid duplication, the EEC Commission opted for the integration of Natura 2000 funding into existing Community funds: Agricultural Fund for Rural Development (AFRD), European Regional Development Fund (ERDF), European Social Fund (ESF), European Maritime and Fisheries Fund (EMFF), Cohesion Fund (CF), LIFE+Nature and Biodiversity, Seventh Research Framework Program (FP7),... [32].

Among all of them, the LIFE program only offers specific

7 The process of designating the place as a SAC cannot be extended beyond a period of 6 years from its designation as a SCI in the Official Gazette of the European Communities and culminates in a ministerial decree and subsequent publication in the respective official state gazette. aid for biodiversity and Natura 2000. In this way, investments to be made in places included in Natura 2000 are preferably channeled through Community instruments for financing measures related to nature conservation, to rural or regional research and development. The integration of the different funds facilitates that the management of the spaces of the Natura 2000 Network is the result of the different European policies of spatial planning, complementary to each other from the perspective of environmental conservation [33]. As the process of preparing the management plans has progressed, the availability of financial and other resources necessary for their application becomes the main issue to be taken into consideration.

The Biodiversity Strategy approved in 1998 by the European Union included among the priority objectives the full implementation of the Habitats and Birds Directives (92/43/EEC and 79/409/ EEC) and support for the creation of networks of declared spaces, especially the Natura 2000 Network [34]. With the approval of the strategy on biological diversity, the Commission took the first step in fulfilling its main obligation as a contracting party to the Convention on Biological Diversity (CBD). The Heads of State, at the European Council held in Gothenburg in June 2001, set a goal to stop the loss of biodiversity by 2010 [35]. In line with all this, the VI Community Environment Program (20022012) contemplated the application of the Natura 2000 program among the measures envisaged in the action plan corresponding to the natural resources conservation sector [36]. The network, however, accumulated a significant delay and, still, in 2004, the year initially established for its completion, a significant effort was required to finalize the phase of selection and designation of sites [29].

The considerable delay in the planned timetable has had important consequences in achieving the goal of halting the loss of biodiversity in Europe, as it contributed to delaying the adoption and direct management of appropriate protection measures to halt the loss of biodiversity. biodiversity. According to the 2001-2006 biogeographic assessment reports, a favorable conservation status, the primary objective of the Directive, was achieved only by $17 \%$ of the habitat types and species [30]. Failure to meet the objective of halting the loss of biodiversity by 2010 led European environmental officials to redouble their efforts in favor of conservation. The Biodiversity Strategy to 2020, approved by the European Commission on May 31, 2011, set the first objective to complete the full implementation of the Habitats Directive in time [37]. With this, the European Union did nothing but put into practice the commitments assumed to develop strategies and action plans in the field of biological diversity with 2020 as the time horizon, within the framework of the Tenth Conference of the Parties, held from 18 to 29 of October 2010 in Nagoya (Japan) by the signatory countries of the Convention on Biological Diversity (1993).

Despite the progress made in nature conservation, the loss of biodiversity has not stopped, since in 2015, it was estimated that the poor state of conservation affected $60 \%$ of species and $77 \%$ of habitat types protected in European 
territory [16, 20, 31, 38]. Species, such as freshwater fish, and habitats, such as natural grasslands and wetlands, ecosystems, in which the richness of species is concentrated on European territory, constituted the areas, in which the state of conservation had been degraded in such a way. worrying. The culmination of marine habitats, the achievement of effective management and the obtaining of the necessary resources to finance the Natura 2000 Network were still pending challenges and aspects, in which it was essential to advance in the short term, to achieve the implementation of the actions foreseen in objective 1 of the Biodiversity Strategy to 2020 [38].

The European Court of Auditors, in its report evaluating the management, financing and control deployed in the implementation of the Natura 2000 Network, alerted the Commission to the need to intensify efforts in order to contribute more to the implementation of the ambitious objectives of the Biodiversity Strategy until 2020 [39]. In order to realize all the potential contained in Natura 2000, the auditing examination concluded with a series of recommendations to achieve a) full implementation of the Directive (greater institutional coordination, compliance with conservation measures within the established execution deadlines, improvement in the quality of environmental assessments, verification of the application of mitigation measures,...), b) adequate financing and cost accounting (exact and complete estimate of the costs associated with the application of conservation measures) and c) the precise measurement of the results achieved by Natura 2000 (monitoring of the performance achieved in the field of conservation in relation to the financing programs executed and standardized and approved surveillance plans to regularly measure the effectiveness achieved in the conservation objectives. marked). Finally, the report showed the need to advance in fields such as the observance and development of the measures adopted regarding the conservation and implementation of the most appropriate financing mechanisms for this.

The spaces included in the Natura 2000 Network, according to data updated to March 2018, totaled 27.758 areas, with an surface of $1.322 .630 \mathrm{~km}^{2}$ and a representation of just over $18 \%$ of the European territory [40]. The implementation of the largest coordinated global network of protected areas began its culmination process in 2004, precisely the year in which, according to the initially established schedule, the network should be definitively completed. On December 29 of that year, the Official Journal of the European Union published the Commission Decision of December 7, 2004, which approved, in accordance with Council Directive 92/43/EEC, the state list of SCIs in the Atlantic biogeographic region, subsequently updated by Decision 2010/43/EC. The list corresponding to the Mediterranean region was published by Decision 2006/613/EC of July 19 and was expanded years later by Decision 2010/45/EC. The lists mentioned, corresponding to the Kingdom of Spain, include the LICs located in the Autonomous Community of the Basque Country.

\section{Regulations Transposed in a Divergent Way}

The transposition of European regulations on the Natura 2000 Network into Spanish legislation was carried out by Royal Decree 1997/1995 and Law 42/2007, of December 13, on Natural Heritage and Biodiversity. The Law establishes as a mandatory measure the drafting of management plans, which are entrusted, on the one hand, with addressing the conservation objectives of the place designated as SAC and establishing, on the other, the appropriate action guidelines to maintain the long-term space in a favorable state of conservation and also set the most appropriate regulatory, administrative and contractual provisions for it. The Royal Decree grants the Autonomous Communities the power to designate SCI and SAC spaces in accordance with the criteria provided in Annex III of the Habitats Directive, as well as to adopt the conservation measures corresponding to species and spaces.

In this line, the norm contemplates that within the National Strategic Plan on Natural Heritage and Biodiversity to be carried out jointly by the Autonomous Communities and the central Government, the development of conservation guidelines, which constitute the common framework, that guides planning and management of the spaces of the Natural Network 2000. The agri-environmental measures, the custody of the territory and the territorial exploitation contracts are tools foreseen to be able to start up, but their mandatory execution is not established, nor, consequently, any action program based on dialogue, negotiation and agreement. The decentralization of competence is accompanied by a technocratic-formal regulation of processes such as the selection of designated spaces, the demarcation of their perimeter, the establishment of management measures, the setting of production limitations, etc.

The Spanish list of Natura 2000 sites is structured into four biogeographic regions: alpine (a large part of the Pyrenees), atlantic (Cantabrian Spain), mediterranean and macaronesian (Canary Islands). In the four biogeographic regions, there are seventy-six types of habitats and one hundred forty-five animal and plant species of community interest, of which, respectively, nineteen and sixty-four are priorities.. The Autonomous Communities proposed the sites to the General Directorate of Natural Environment and Forest Policy of the Ministry of the Environment and Rural and Marine Affairs, who acted as general coordinator of the entire process and was responsible for their official transmission to the European Commission. Spain is one of the European countries with the largest territorial participation in the Natura 2000 Network. With data from 2018, the 1.863 land and marine sites included in Natura 2000 comprised 222.356 $\mathrm{km}^{2}$, which represented around a quarter of the national surface and above $18 \%$ of the European extension designated with this protection figure [41].

Most of the Spanish sites in the Natura 2000 Network, around $90 \%$, are located in rural areas. In some cases, the 
inclusion of a site in the Natura 2000 Network may entail costs generated by the existence of uses that, because they are incompatible with the natural assets to be conserved, must be limited. In any case, the designation as a Natura 2000 area represents an opportunity to stimulate the sustainable rural development of the area by promoting plans, projects and activities compatible with the conservation of habitat and protected species. In Spain, the different autonomous communities have powers to draw up and manage their own Rural Development Plans, which must include specific measures to help farms located in Natura 2000 areas. At the national level, Law 45/2007 for the Sustainable Rural Development grants preferential treatment to Natura 2000 areas, which are considered a priority when applying the Sustainable Rural Development Program in fields such as the distribution of regional economic incentives and the creation and maintenance of employment.

The proposal for the designation of SCIs and ACWBs with the delimitation of the respective conservation objectives for their transformation into SACs corresponds to the Basque Government within the territory of the Basque Autonomous Community (BAC). These attributions began to be put into practice by the agreements made in the Governing Council on December 23, 1997, November 28, 2000 and June 10, 2003. The number of sites proposed and designated by community institutions as SACs rises to forty-seven and include mountainous areas, representative areas of forests of unique ecological value (holm oak, cork oak, oak-island), wetlands, rivers, estuaries and coastal-marine spaces. The areas declared ACWB add four and as many spaces simultaneously the declaration of ACWB and SACs. A significant number of the Basque areas in the Natura 2000 Network are also part of the autonomous network of protected areas in the form of natural park and Biosphere Reserve. The fifty-five sites in the Natura 2000 Network currently cover 146.788 hectares, $20.03 \%$ of the surface in the BAC.

The Natura 2000 spaces in Alava territory add up to twenty-nine and cover 84.772 hectares $(28.2 \%)$. These places represent more than half $(56.5 \%)$ of those existing in the BAC. The areas of Alava in the Natura 2000 Network are essentially spread over mountains owned by local entities, approximately nine out of every ten hectares declared with this protection figure. Most of them are forests declared of public utility, in which the technical supervision and inspection of the forest engineers is now superimposed on the evaluation and expert opinions of scientific experts and naturalists. The designation as a European protected area has represented a new loss of power in the capacity of Alava local entities when making decisions about future actions to be carried out in their forest heritage.

The Natura 2000 Network is an opportunity to establish bridges with local communities, private owners and social agents with interests in these protected areas. Despite their status as owners and the role played in the modeling of the habitats and landscapes selected to be designated as a European protected area, the local entities of Alava, however, were not consulted in the designation process or in the demarcation of the perimeter of protected areas. The processes for designating areas and planning for Natura 2000 have been carried out independently of the local population [41]. By way of example, it can be pointed out that the regional managers of the environmental area did not summon the administrative boards and population affected by the declaration of the Gibijo-Arkamo-Arrastaria SAC to participate until the summer of 2012, that is, more than fourteen years after that the inclusion process of the Natura 2000 Network should officially begin, by means of a Governing Council Agreement of December 23, 1997; specifically, the call ran through the format of an informative workshop-talk lasting a few hours, when addressing the drafting of the corresponding draft management plan [42]. The local entities have not participated either in the process of preparing the Management Plans, beyond the minimum formal channels allowed by the public information phase. Therefore, it is not surprising that the inhabitants of rural Alava perceive inclusion in the Natura 2000 Network as a bureaucratized process and disconnected from collective plans and projects at the local level.

This approach, in any case, does not deviate and coincides with the disfigured socio-economic treatment developed by the Basque administration with respect to environmental conservation problems. Despite the fact that one of the functions entrusted by regional legislation is the promotion of rural development in the immediate surroundings, the compatibility of conservation and development and, ultimately, the revitalization of agricultural holdings and the economy of the localities included in declared spaces. protected, all these issues constitute today one of the main pending challenges of the regional environmental policy [43].

\section{Conclusion}

Failure to comply with the objective of halting the loss of biodiversity in 2010 led European officials to redouble their efforts to definitively close the implementation of the Habitats Directive. The scope of application of the Natura 2000 measures includes, however, those rural areas, in which extensive agricultural and livestock production systems dominate. The fundamental point to take into account for anyone who is truly concerned about biodiversity, resides in the "ecological footprint", that is, in the impact exerted on the natural environment by the human community through its specific production models and lifestyle.

From this perspective, the decisive battle for sustainability is fought in urban and semi-urban areas, where the future of conservation will be won or lost to the extent that the control of carbon dioxide emissions gains strength, orderly and cautious management of water use, waste recycling, energy efficiency of buildings, improvement of public infrastructures or change in consumption patterns. The Natura 2000 Network undoubtedly represents an instrument, the consistent implementation of which will redound in the fight to improve biodiversity. However, stopping the advance of biological degradation processes will require the adoption 
of complementary structural measures. The improvement of the natural state of biodiversity today involves the design of alternative models in the organization of the prevailing habits of production and consumption in society as a whole.

The implementation carried out on the ground of Natura 2000 to date in Spain and more specifically, in the Autonomous Community of the Basque Country, can be described in general terms as regulatory and technocratic. The managers and experts, despite being aware that the ecological dimension is part of a dynamic and living socioeconomic space, have nevertheless channeled relations with the economic and social agents involved (local institutions, ranchers, hunters, ...) through eminently formal and bureaucratic channels.

In short, the commitment of the Natura 2000 Network for the sustainable development of the territory, for integrating socio-economy and conservation of natural values and for the active involvement of institutions and people affected in environmental conservation tasks, ends up being totally disfigured, when you go through the different steps and descend from the community legal texts to their transposition in the environmental regulations of state and autonomous areas and from there, to their real materialization in the specific territories classified as protected spaces. The struggle for biodiversity today has a complex, long and problematic road ahead in Europe.

\section{References}

[1] SADELER, N. (1993). La Directive 92/43/CEE concernant le conservation des hábitats naturels ainsi que de la faune et de la flore sauvages: vers le reconnaisssance d'un patrimoine naturel de la Communauté Européenne (Directive 92/43/EEC concerning the conservation of natural habitats and of wild fauna and flora: towards the recognition of a natural heritage of the European Community). Revue du Marché commun et de 1'Union européenne, 364, 24-32.

[2] EEC (1995). Wise use and conservation of wetlands, Communication from the Commission to the Council and the European Parliament. COM (95) 189 final, 29 May 1995.

[3] EEC (1988). Environment and Agriculture, COM (88) 338 final, Brussels, 16.08.1988.

[4] EEC (1989). The Common Agricultural Policy and the conservation and recovery of the vegetation cover, Memorandum of the Presidency of the Council of Ministers of Agriculture, Luxembourg, June 19-20, 1989/ La Política Agraria Común y la conservación y recuperación de la cubierta vegetal. NOVAS GARCÍA, A. (ed.). El sector forestal y la CEE, Madrid: ICONA, 385-387.

[5] EEC (1991). The development and future of the CAP. Reflections paper of the Commission. Communication of the Commission to the Council. COM (91) 100 final, 1 February 1991.

[6] EEC (1997). Council Directive 97/62/EC, of October 27 adapting adapting to technical and scientific progress Directive 92/43/EEC on the conservation of natural habitats and of wild fauna and flora, Official Journal of the European Communities, No 305, November 8, 1997, 42-65.
[7] EEC (2000). Managing Natura 2000 sites. The Provisions of article 6 of the Habitats Directive 92/43/EEC, Luxembourg: Office for Official Publications of the European Communities.

[8] EEC (2019). Managing Natura 2000 sites. The Provisions of article 6 of the Habitats Directive 92/43/EEC (2019/C 33/01), Official Journal of the European Union, January 25, 2019.

[9] EEC (2002). Assessment of plans and projects significantly affecting Natura 2000 sites. Methodological guidance on the provisions of Article 6 (3) and 6 (4) of the Habitats Directive 92/43/EEC, Luxembourg: Office for Official Publications of the European Communities.

[10] TRAÏNI, C. (2005). Les stratégies d'accréditation des acteurs locaux et les jeux de légitimité dans la mise en œuvre de la directive Natura 2000 (Accreditation strategies for local actors and legitimacy games in the implementation of the Natura 2000 directive). DUBOIS, J. y MALJEAN-DUBOIS, S., (dirs.). De l'in-jonction européenne aux négociations locales, Paris: La Documentation française, 129-148.

[11] PINTON, F., ALPHANDÉRY, P., BILLAUD, J-P., DEVERRE, CH., FORTIER, A. Y LEFEBVRE, C. (2006). (The construction of the Natura 2000 network in France. A European biodiversity conservation policy put to the test), Paris: La Documentation française.

[12] GUHA, R. y GADGIL, M. (1993). Los hábitats en la historia de la humanidad (Habitats in the history of mankind). Ayer, 11, 49-110.

[13] PRIEUR, M (2003). La tutela comunitaria degli habitat naturali (Community protection of natural habitats). AMIRANTE, D. (ed.), La conservazione della natura in Europa. La Direttiva Habitat ed il processo di costruzione della rete "Natura 2000", Milano: Franco Angelli, 13-29.

[14] PARRA, F. (2005) La cultura del territorio (La naturaleza contra el campo) (The culture of the territory. Nature against the countryside). Ecología política, 29, 7-15.

[15] GARAYO URRUELA, J. Ma (2001) Los espacios naturales protegidos entre la conservación y el desarrollo (Protected natural spaces between conservation and development). Lurralde, 24, 271-293.

[16] LEPART, J. y MARTY, P. (2006). Des réserves de nature aux territoires de la biodiversité. L'example de France (From nature reserves to areas of biodiversity. The example of France). Annales de géographie, No 651, 485-507.

[17] FORTIER, A. y ALPHANDÉRY, P. (2005). Négociations autour de la biodiversité: la mise en oeuvre de Natura 2000 en France (Negotiations around biodiversity: the implementation of Natura 2000 in France). MARTY, P., VIVIEN, F-D., LEPART, J. y LARRÉRE, R. (coords.). Les Biodiversités. Objets, Théories, Practiques, Paris: CNRS éditions, 227-240.

[18] FABIANI, J. L. (1985): Science des écosystémes et protection de la nature (Ecosystem science and nature protection). CADORET, A. C. Protection de la nature: histoire et ideologie. De la nature a l'environnement, Paris: L'Harmattan, 75-93.

[19] PIPIEN, G. (2005). La directive "hábitats", une avancée en faveur du patrimoine naturel (The habitats directive, a step forward in favor of natural heritage). DUBOIS, J. y MALJEAN-DUBOIS, S., (dirs.). De l'injonction européenne aux négociations locales, Paris: La Documentation française, 225-239. 
[20] GARDE, L. (2005). Faut-il sauver Natura 2000? (Should we save Natura 2000?). DUBOIS, J. y MALJEAN-DUBOIS, S., (dirs.). De l'injonction européenne aux négociations locales, Paris: La Documentation française, 161-182.

[21] LARRÉRE, R. y FLEURY, P. (2004). Malentendus, incompréhensions et accords dans la gestion de la biodiversité (Misunderstandings, lack of understanding and agreements in the management of biodiversity). Fourrages, 179, 307-318.

[22] LEPART, J. y MARTY, P. (2005). La mise en oeuvre du Réseau Natura 2000: questions á 1'ecologie scientifique (La mise en oeuvre du Réseau Natura 2000: questions à l'écologie scientifique). DUBOIS, J. y MALJEAN-DUBOIS, S., (dirs.). De l'in-jonction européenne aux négociations locales, Paris: La Documentation française, 27-44.

[23] EEC (1992). Council Directive 92/43/ EEC of 21 May 1992 on the Conservation of Natural Habitats and of Wild Fauna and Flora, Official Journal of the European Communities, No 206, July 22, 1992, 7-50.

[24] UICN (CNPPA) (1994): Guidelines for Protected Area Management Categories. Lignes directrices pour les catégories de gestion des aires protégées. Directrices para las Categorías de Manejo de Áreas Protegidas, Gland (Suiza).

[25] GARAYO URRUELA, J. Ma (1996). Concepción integrada de la conservación de la naturaleza y categorías de espacios naturales y protegidos (Integrated conception of nature conservation and categories of natural and protected areas). Lurralde, 19, 251-234.

[26] MILIAN, J. (2001). Le projet Natura 2000 et la protection du patrimoine naturel. L'exemple des sites expérimentaux pyrénéens (The Natura 2000 project and the protection of the natural heritage. The example of Pyrenean experimental sites). Etudes rurales, 157-158, 173-194.

[27] DUBOIS, J. y MALJEAN-DUBOIS, S., (dirs.) (2005). De l'injonction européenne aux négociations locales (From European injunction to local negotiations), Paris: La Documentation française.

[28] MARQUETTE, A. (2007). La gestión française des sites classés "Natura 2000" (French management of sites classified as Natura 2000), Lyon: Institute d'Etudes Politiques (Université Lumiére Lyon II), Mémoire de fin d'etudes.

[29] EEC (2004). Report from the Commission on the implentation of the Directive 92/43/EEC on the conservation of natural habitats and of wild fauna and flora, COM (2003) 845 final, Brussels, 5.1.2004.

[30] EEC (2009). Report from the Commission to the Council and the European Parliament. Composite Report on the Conservation Status of Habitat Types and Species as required under Article 17 of the Habitats Directive, COM (2009) 358 final, Brussels, 13.07.2009.

[31] EEC (2015). Report from the Commission to the Council and the European Parliament. The State of Nature in the European Union. Report on the status of and trends for habitat types and species covered by the Birds and Habitats Directives for the 2007-2012 period as required under Article 17 of the Habitats Directive and Article 12 of the Birds Directive, Brussels, 20.5.2015, COM (2015) 219 final.
[32] EEC (2004). Communication from the Commission to the Council and the European Parliament - Financing of Natura $2000\{$ SEC (2004)770\} \{SEC (2004)771\}/*COM/2004/0431 final $* /$.

[33] WWF/Adena (2008). Mitos sobre la red Natura 2000: Respuestas a las dudas más importantes sobre la red europea de espacios protegidos (Myths about the Natura 2000 network: Answers to the most important questions about the European network of protected areas), Madrid.

[34] EEC (1998). A European Community biodiversity strategy, Communication from the Commission to the Council and the European Parliament, COM (98) 42 final, Brussels, 04.02.1998.

[35] EUROPEAN ENVIRONMENT AGENCY (2009). Halting the loss of biodiversity by 2010: proposal for a first set of indicators to monitor progress in Europe, Technical report No $11 / 2007$.

[36] EEC (2001). Biodiversity Action Plans in the areas of Conservation of Natural Resources, Agriculture, Fisheries, and Development and Economic Co-operation, Communication from the Commission to the European Council and Parliament, COM (2001) 162 final, Brussels, 27.3.2001.

[37] EEC (2011). Communication from the Commission to the European Parliament, the Council, the European Economic and Social Committee and the Committee of the Regions. Our life insurance, our natural capital: an EU biodiversity strategy to $2020 \quad\{$ SEC (2011)540 final $\} \quad\{$ SEC (2011)541 final $\} / * \mathrm{COM} / 2011 / 0244$ final */, Brussels, 3.06.2011.

[38] EUROPEAN ENVIRONMENT AGENCY (2015). The state of nature in the EU. Reporting under tue EU Habitats and Birds Directives 2007-2012, Luxembourg: Office for Official Publications of the European Union.

[39] EUROPEAN COURT OF AUDITORS (2017). More effort is needed to fully implement the Natura 2000 Network (submitted in accordance with Article 287 TFEU, paragraph 4 , second subparagraph), accompanied by the Commission's responses, Luxembourg, Special Report No 1/2017.

[40] EEC (2018) Natura 2000. Nature Information Bulletin, 44, February.

[41] GARCÍA FERNÁNDEZ-VELILLA, S., JIMÉNEZ LUQUIN, A. y ALONSO SEMINARIO, C. (2011). Decidir juntos para gestionar mejor. Manual de planificación participativa en áreas protegidas (Decide together to better manage. Manual of participatory planning in protected areas), Vitoria-Gasteiz: Departamento de Medio Ambiente, Planificación territorial y Agricultura.

[42] GARAYO URRUELA, J. M ${ }^{\mathrm{a}}$ (2016). Zona Especial de Conservación Arkamo-Gibijo-Arrastaria (Inacaba implementación de los fines de Natura 2000). (ArkamoGibijo-Arrastaria Special Conservation Zone (Unfinished implementation of Natura 2000 goals), 100 páginas, memoria inédita.

[43] ETXANO GANDARIASBEITIA, I. (2009). Desarrollo rural en Espacios Naturales Protegidos. El caso del Parque Natural de Gorbeia (1994-2008). (Rural development in Protected Natural Areas. The case of the Gorbeia Natural Park (19942008). Lurralde, 32, 197-226. 